\title{
Development of Rocket Telemetry in Chamber Gas Pressure Monitoring with the MPXV7002DP Gas Pressure Sensor
}

\author{
Anggara Trisna Nugraha, Dadang Priyambodo \\ Marine Electrical Engineering Shipbuilding Institute of Polytechnic Surabaya, Surabaya \\ Jl. Teknik Kimia Keputih Sukolilo, Surabaya 60111, Indonesia
}

\begin{tabular}{ll}
\hline \multicolumn{1}{c}{ Article Info } & Abstract \\
\hline $\begin{array}{l}\text { Article History: } \\
\text { Received Sept } 15,2020\end{array}$ & $\begin{array}{l}\text { Telemetry is a process used to measure or record a physical quantity at a location far from the center } \\
\text { of processing the measurement results. Telemetry systems on unmanned aerial vehicles can provide } \\
\text { information such as position, altitude, direction, and status of the vehicle itself in real-time when the air } \\
\text { Revised Sept } 30,2020 \\
\text { Accepted Oct } 21,2020\end{array}$ \\
$\begin{array}{l}\text { veaction that occurs in the rocket. Implementation of the strain gauge sensor through the MPXV7002DP } \\
\text { gas pressure sensor, the amount of gas pressure is obtained at the time of combustion of the rocket and } \\
\text { sent via wi-fi telemetry Pixhawk 447 MHz, the data on a laptop can be shown the gas pressure generated } \\
\text { in the rocket chamber through the display of the Borland Delphi program with a distance of 150 m. }\end{array}$ \\
$\begin{array}{l}\text { Keywords: } \\
\text { Rocket }\end{array}$
\end{tabular}

MPXV7002DP

Accelerometer

Telemetry

\author{
The Corresponding Author: \\ Anggara Trisna Nugraha \\ anggaranugraha@ppns.ac.id, \\ Marine Electrical Engineering \\ Shipbuilding Institute of Polytechnic Surabaya \\ J1. Teknik Kimia Keputih Sukolilo, Surabaya 60111, Indonesia
}

\section{INTRODUCTION}

Rockets have a strategic meaning, they can be used in both peace and defense missions. This depends on the payload carried by rocket [1] - [3]. If the cargo carried is in the form of research instruments, communication tools, and others, it is a rocket for peaceful purposes [4] - [5]. Whereas weaponry rockets that carry explosives (warheads) that can destroy our rockets for defensive purposes. Therefore, countries that master rocketry technology independence well, will be respected by other countries around the world [6].

Applying the MPXV7002DP sensor to convert pressure into electric voltage in measuring gas pressure because it is impossible to do it manually. But the development of technology is now possible by using a gas pressure sensor MPXV7002DP which then the pressure data will be sent via Wi-fi [7] - [8]. Telemetry is the process of measuring the parameters of an object (objects, space, natural conditions) whose measurement
This work is an open-access article and licensed under a Creative Commons Attribution-ShareAlike 4.0 International License (CC BY-SA 4.0 $)$.

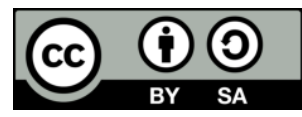

results are sent to another place through the process of sending data either using cables or without using cables (wireless). is expected to provide convenience in measuring, monitoring, and reducing barriers to obtaining information [9]. With the above problems, the author tries to find a solution by making "TELEMETRY DEVELOPMENT IN ROCKETS IN GAS CHAMBER PRESSURE MONITORING". With this implementation, the specific rocket impulses can be measured based on the combustion pressure of the chamber [10].

\section{MATERIALS AND METHODS}

This chapter will discuss some brief literature reviews or references.

\section{A. Telemetry Pixhawk $433 \mathrm{MHz}$}

This $433 \mathrm{MHz}$ Pixhawk Telemetry Module uses the SPI (Serial Peripheral Interface) interface to communicate. The working voltage of this module is $5 \mathrm{~V}$ DC. This telemetry module can transmit data up to a distance of $300 \mathrm{~m}$ at a 
Journal of Electronics, Electromedical, and Medical Informatics (JEEEMI)

Vol. 2, No. 3, October 2020, pp. 103-107

DOI: 10. 35882/jeeemi.v2i3.3

ISSN:2656-8632

maximum speed of $250 \mathrm{kbps}$. The $433 \mathrm{MHz}$ frequency wave propagation system is not sensitive to reflection phenomena, especially to wall resistance, metal structures, and water. In terms of power consumption, the frequency of $433 \mathrm{MHz}$ requires less energy per bit than higher frequencies. The $433 \mathrm{MHz}$ system also uses a small antenna, the $433 \mathrm{MHz}$ frequency has relatively lower attenuation than other ISM frequencies. (Fig. 1.)

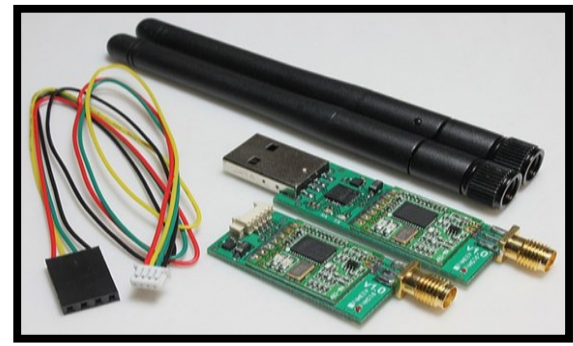

Fig. 1. Telemetry pixhawk $433 \mathrm{MHz}$ module

\section{B. SD (Secure Digital) Data Logger}

The SD card module is a module that functions to read and write data or from an SD card. This module has interfacing using SPI communication. The working voltage of this module can use a $3.3 \mathrm{~V} \mathrm{DC}$ or $5 \mathrm{~V}$ DC voltage level, which can be used either. This module is suitable for making devices that require nonvolatile storage (data will be stored even if it does not get a supply voltage) with a large capacity, up to Gigabytes. This module is widely used for making medical recordings, music recorders and playback, data loggers, and also for database creation. The data recorder is also called a data logger. In general, a simple data recorder consists of a controller, sensors, and storage media. (Fig. 2.)

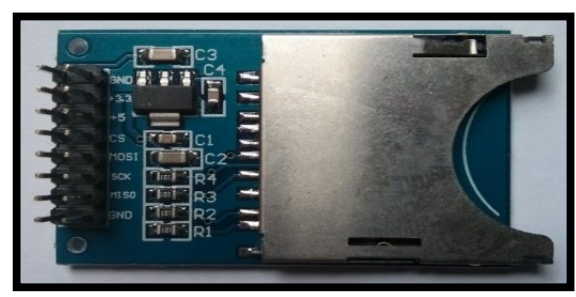

Fig. 2. SD module

\section{Fill Rocket Push (Propellant)}

A propellant is a mixture of chemical compounds, in the form of black powder which has low pressure and is used as a thrust filler for rockets or munitions which, if given the right stimulation, will produce or cause gas pressure in the rocket chamber. This solid push filling consists of several shapes including flat, sheet, round, rod, or hollow cylinder shapes. The difference in shape is intended to determine different pressure times, adjusted for the user. The energy source in the rocket is the gas pressure which is influenced by the specific energy, the amount of mass used, the amount of energy will affect the forward motion of the rocket, adjusted for the user. (Fig. 3.)

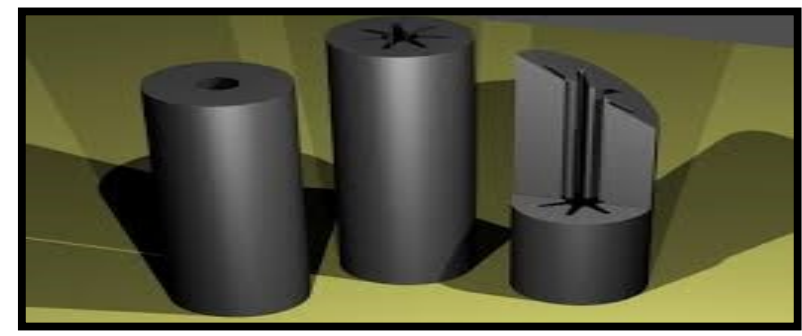

Fig. 3. Propellant shapes

\section{Mechanical Design}

The mechanical design of the rocket is shown in Figure 4.

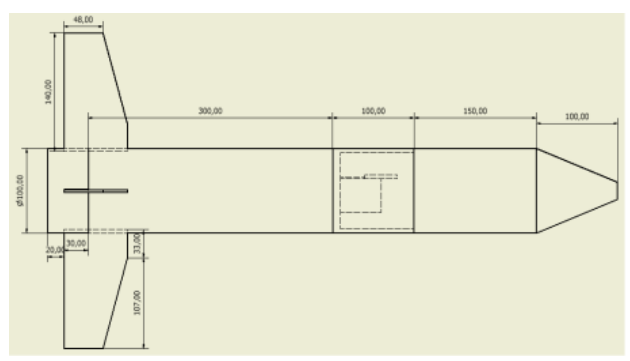

Fig. 4. Side view of the rocket

TABLE I. ROCKET`S PART AND FUNCTION INFORMATION

\begin{tabular}{lll}
\hline Number & Name of part & Function \\
\hline 1 & $\begin{array}{l}\text { Parachute`s } \\
\text { place }\end{array}$ & $\begin{array}{l}\text { Save the parachute before } \\
\text { separation }\end{array}$ \\
\hline 2 & $\begin{array}{l}\text { The place of } \\
\text { electronic }\end{array}$ & $\begin{array}{l}\text { The place of the rocket's } \\
\text { load consisting of the } \\
\text { electronic module }\end{array}$ \\
\hline 3 & $\begin{array}{l}\text { Rocket`s } \\
\text { body }\end{array}$ & $\begin{array}{l}\text { Rocket launcher by water } \\
\text { filling and wind }\end{array}$ \\
\hline 5 & $\begin{array}{l}\text { Rocket`s } \\
\text { wings }\end{array}$ & $\begin{array}{l}\text { maintain the rocket stability } \\
\text { when it gliding in the air }\end{array}$ \\
\hline 5 & Nozzle & $\begin{array}{l}\text { Layer between rocket and } \\
\text { launcher }\end{array}$ \\
\hline
\end{tabular}

\section{E. Telemetry Design}

The Pixhawk Telemetry Module is a long-range communication module that utilizes the ISM (Industrial, Scientific, and Medical) $433 \mathrm{MHz}$ RF band. This $433 \mathrm{MHz}$ RF module consists of a transmitter (TX) and receiver (RX), which are generally used for remote control. This module uses the SPI (Serial Peripheral Interface) interface to communicate. The working voltage of this module is $5 \mathrm{~V}$ DC. This telemetry module can transmit data up to a distance of $300 \mathrm{~m}$ at a maximum speed of $250 \mathrm{kbps}$. (Fig. 5.) 


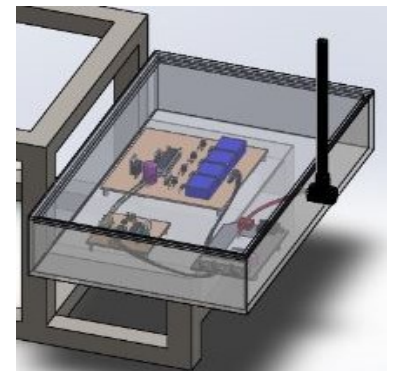

Fig. 5. Telemetry place design

\section{F. Block diagram of how telemetry works}

In the block diagram above, it is explained that the gas pressure measurement data will be processed and transmitted via the Pixhawk $443 \mathrm{MHz}$ and then the Pixhawk will be received on the receiver side which will then be processed and displayed in graphic form. (Fig. 6., \& Fig. 7.)

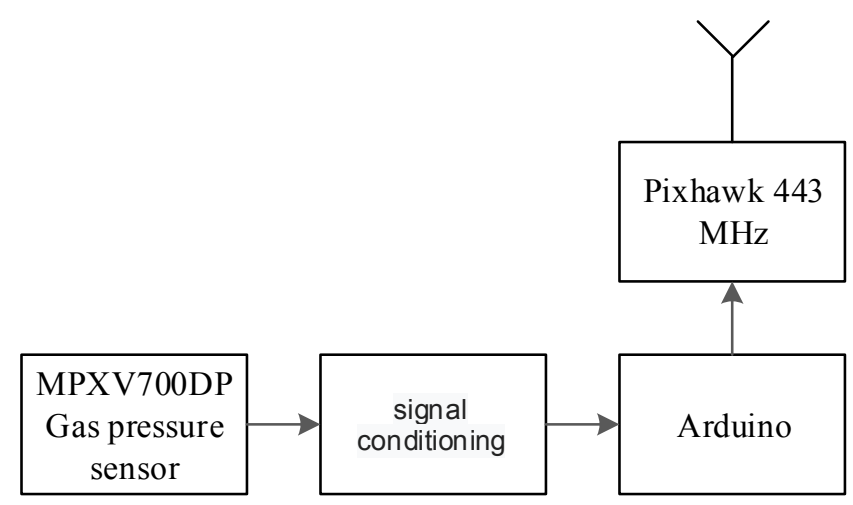

Fig. 6. Block the diagram of the transmitter

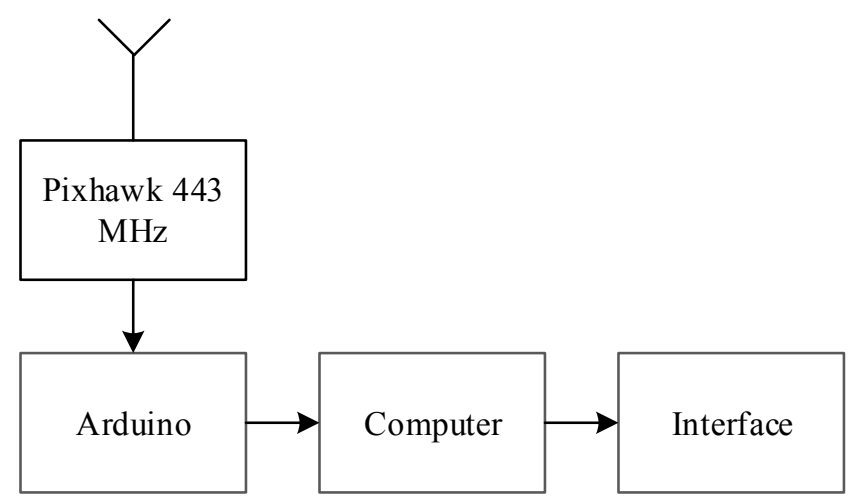

Fig. 7. Blog receiver diagrams
G. Tools and materials

1. Telemetry Pixhawk $433 \mathrm{MHz}$

2. Arduino

3. MPXV7002DP sensor

4. Computer

5. Fill Rocket Push

6. SD module

\section{RESULTS}

A. Realtime testing of the whole system

Realtime system testing is done by combining all circuit blocks into one so that the system will be tested completely to find out the data sent by the transmitter circuit and which will be received by the receiver system and then displayed in the realtime application in the form of tables and graphs. The data received by the application will be compared with the data stored in the SD module. This aims to find out the data stored in the SD which is received by real-time applications in tables and graphs. (Fig. 8.)

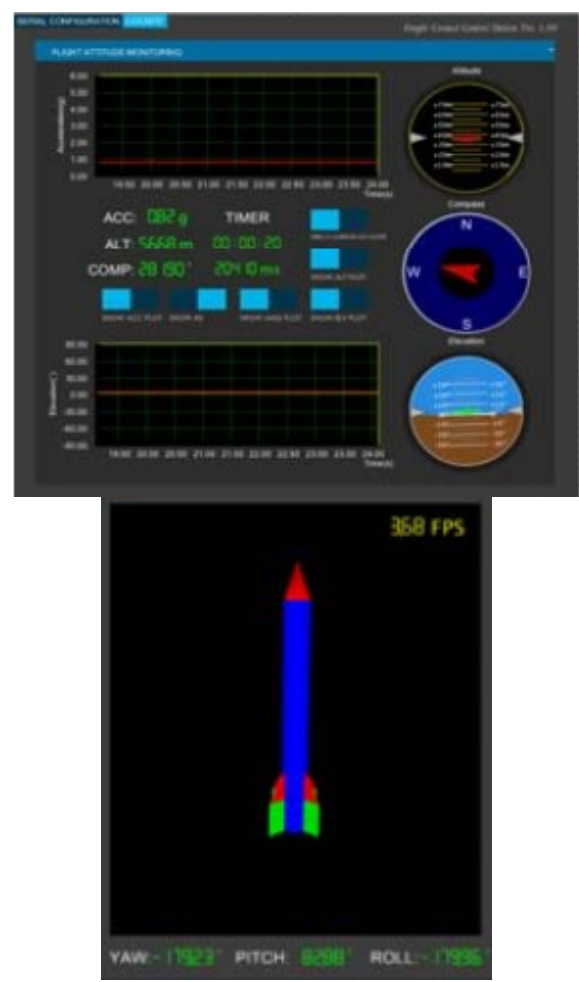

Fig. 8. The main view on the computer

When testing the tool, the distance used between the transmitter and receiver is 150 meters. The propellant composition used was sucrose, $\mathrm{KNO} 3$, and activated carbon with a ratio of $55 \% \mathrm{KNO} 3,35 \%$ sucrose, and $10 \%$ activated 
carbon. Figure 9. shows a graph of the measurement of propellant combustion gas pressure on a rocket.

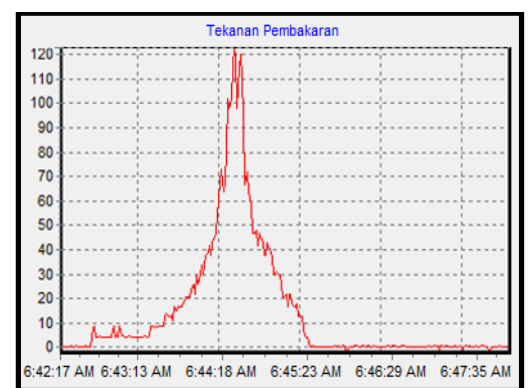

Fig. 9. Graph of measuring result burning pressure distance 150 meters

Figure 10. shows when testing the tool, the distance used between the transmitter and receiver is 250 meters. The propellant composition used was $\mathrm{KNO} 3$, sucrose, and activated carbon. Comparison of the composition of these ingredients, namely 60\% Potassium Nitrate (KNO3), and 35\% sucrose, and $5 \%$ activated carbon with a total weight of 100 grams of propellant.

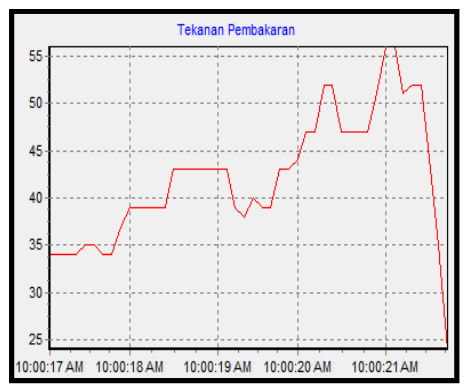

Fig. 10. Graph of measuring result burning pressure distance 250 meters

In the rocket test, the results of the GCS automatic graph plot feature for accelerometer sensor telemetry data can be seen in Figure 8. Based on the graph plot, the accelerometer sensor reads each applied shock with a fairly good response as one of the functions of the accelerometer sensor is a mechanical shock sensor. (Fig. 11.)

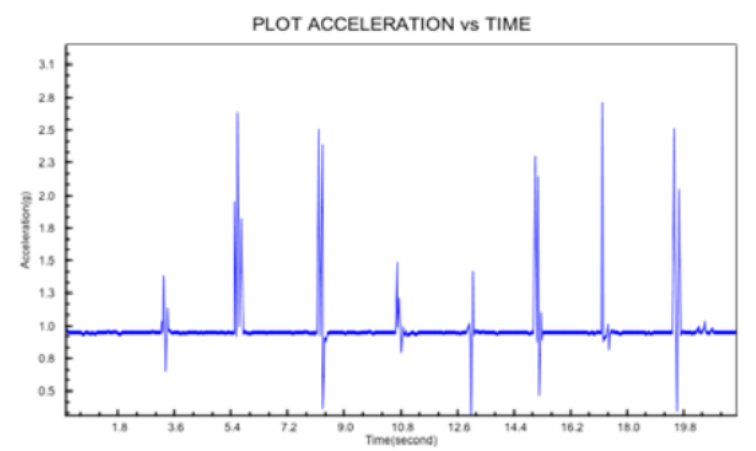

Fig. 11. Result feature of automatic graphic plot GCS data telemetry sensor accelerometer
TABLE II. RESULT OF TELECOMMAND TEST

\begin{tabular}{llll}
\hline $\begin{array}{l}\text { State of } \\
\text { telemetry }\end{array}$ & $\begin{array}{l}\text { Time } \\
\text { (second) }\end{array}$ & $\begin{array}{l}\text { State of } \\
\text { data } \\
\text { package } \\
\text { received }\end{array}$ & $\begin{array}{l}\text { Data } \\
\text { package } \\
\text { quality }\end{array}$ \\
\hline ON & 0.138 & Complete & Good \\
\hline 1.000 & Complete & Good & \\
\hline 2.006 & Complete & Good & \\
\hline 3.020 & Complete & Good & \\
\hline OFF & - & - & - \\
\hline ON & 0.981 & Complete & Good \\
\hline 2.024 & Complete & Good & \\
\hline 3.065 & Complete & Good & \\
\hline
\end{tabular}

TABLE III. ANALYSIS OF TELEMETRY TEST

\begin{tabular}{llll}
\hline $\begin{array}{l}\text { Number. Distances } \\
\text { Meters })\end{array}$ & Transmitter ( TX ) Receiver ( RX ) \\
\hline 1 & 150 & Send 421 data & $\begin{array}{l}\text { Received 421 } \\
\text { data }\end{array}$ \\
\hline 2 & 250 & Send 421 data & Received 427 data \\
\hline
\end{tabular}

Based on testing the distance of the telemetry module that has been carried out at a distance of 150-250 meters, the character data sent can still be received by the laptop well, while at a distance of 150 meters the process of sending data becomes slow and delays due to the distance that is too far, at a distance of 250 meters. those sent can no longer be accepted by the laptop. In this test, the effective distance between the sending and receiving units is 150 meters.

\section{DISCUSSION}

Open tubular rockets were introduced in 2009 by Solovev et al., who fabricated such engines and discussed their propulsion mechanism. The basic structure and propulsion mechanism offered by Solovev et al. are still integral to current rocket design and performance. In particular, the rocket must contain an inner catalytic or reactive surface around a hollow core to provide a favorable nucleation site for the thrust-providing bubbles essential for giving these rockets their momentum. Such thrust, which is the force propelling the rocket, is the result of pressure exerted by the bubble ejection. This catalytic layer cannot be exposed to the exterior, so an outer unreactive stabilizing tubular shell must be included. Furthermore, the engine must be mildly conical or asymmetric in shape to favor the fuel intake at the smaller opening and bubble ejection out of the other larger opening. 
The propulsion behavior of rockets at both extremes of the length scale is strongly dependent on the rocket geometry and composition. Macroscale rockets are subject to extremely highpressure drag, which dictates the overall form of the rocket exterior, and stability concerns demand careful attention to the rocket shape and center of mass. The material and structural composition of large rockets are also important for heat resilience, drag reduction, and strength against stresses when the rocket undergoes maximum dynamic pressure. Likewise, careful geometric considerations must be made to enhance the performance of rockets at the nanoscale. The conical shape is crucial for achieving effective unidirectional bubble ejection, and control of the length, entry, and exit radii is also crucial for optimizing the speed of small-scale rockets, as discussed above. The choice of the outer layer is important to reduce the viscous drag on the rocket, and additional functionalities can be implemented through the careful design of these outer layers. Current fabrication processes are still predominantly planar techniques, which makes three-dimensional tubular structures, let alone with structures with hollow inner cores and conical geometries, difficult to realize. Here, we detail the main approaches for fabricating commonly used rockets.

\section{CONCLUSION}

Based on the results of tests carried out on the system. This is evidenced by the results of the tests carried out giving a success rate of $100 \%$ both in terms of functionality, response, and system resilience. Besides, the telemetry, telecommand, and visualization processes, in this case, can also work well, marked by the absence of telemetry data defects, delays in data transmission, visualization misinterpretation, and disconnection during system testing.

\section{REFERENCES}

[1] Nugraha, Anggara Trisna. "Tracking Quadcopter Menggunakan Metode Command-Generator Tracker Dengan Efek Integrator." Jurnal Teknologi Elektro 8.2.

[2] Nugraha, Anggara Trisna. "ROBOT PENGURAI ASAP DALAM RUANGAN MENGGUNAKAN T-BOX DENGAN METODE BEHAVIOUR BASED CONTROL." Prosiding SENIATI (2017): B10-1.

[3] Nugraha, A. T., and T. Agustinah. "Quadcopter Path Following Control Design Using Output Feedback with Command Generator Tracker LOS Based At Square Path." Journal of Physics: Conference Series. Vol. 947. No. 1. IOP Publishing, 2018.

[4] Nugraha, Anggara Trisna. "DISTURBANCE REJECTION BERBASIS LOS SAAT TRACKING PADA JALUR LINGKARAN MENGGUNAKAN QUADCOPTER." Prosiding SENIATI (2018): 5056.

[5] Nugraha, Anggara Trisna. "DIRTY AIR FILTER SYSTEM USING BOXED EQUALIZER MQ-8 AND MQ-9 WHEELED ROBOT." JEEMECS (Journal of Electrical Engineering, Mechatronic and Computer Science) 1.1 (2018): 23-26.

[6] Nugraha, A. T., I. Anshory, and R. Rahim. "Effect of alpha value change on thrust quadcopter Qball-X4 stability testing using backstepping control." MS\&E 434.1 (2018): 012207.

[7] Nugraha, Anggara Trisna. "Rancang Bangun Teknologi Pemurni Air." Skripsi. Universitas Jember, Jember.[Diakses tanggal 27 Maret 2016-16: 18 WIB] (2015).

[8] Nugraha, Anggara Trisna, and Trihastuti Agustinah. "Quadcopter path following control design using output feedback with command generator tracker based on LOS." 2017 International Seminar on Intelligent Technology and Its Applications (ISITIA). IEEE, 2017.

[9] Nugraha, Anggara Trisna. Desain Kontrol Path Following Quadcopter Dengan Command Generator Tracker Model Following. Diss. Institut Teknologi Sepuluh Nopember, 2017.

[10] Nugraha, Anggara Trisna. "Desain Kontrol Path Following Quadcopter Dengan Algoritma Line of Sight." Prosiding SENIATI (2017): B9-1. 